\title{
Biodiversity of Escherichia coli bacterial resistance to multidrug isolated on the Dumai coast of Indonesia
}

\author{
FELI FELIATRA ${ }^{1, \bullet}$, MARDALISA MARDALISA $^{1}$, IRWAN EFFENDI $^{1}$, ADELINA ADELINA $^{2}$, \\ VANESA ADIBA FELIATRA ${ }^{3}$ \\ ${ }^{1}$ Department of Marine Science, Faculty of Fisheries and Marine Science, Universitas Riau. Jl. HR. Soebrantas KM. 12,5, Kampus Bina Widya, Simpang \\ Baru, Pekanbaru 28293, Riau, Indonesia. Tel./fax.: +62-761- 63275, `email: feliatra@ yahoo.com \\ ${ }^{2}$ Department of Aquaculture, Faculty of Fisheries and Marine Science, Universitas Riau. Jl. HR. Soebrantas KM. 12,5, Kampus Bina Widya, Simpang \\ Baru, Pekanbaru 28293, Riau, Indonesia \\ ${ }^{3}$ Faculty of Medicine, Universitas Riau. Jl. Diponegoro No. 1, Suka Mulia, Pekanbaru 28133, Riau, Indonesia
}

Manuscript received: 27 June 2021. Revision accepted: 5 December 2021.

\begin{abstract}
Feliatra F, Mardalisa M, Efendi I, Adelina A, Feliatra VA. 2021. Biodiversity of Escherichia coli bacterial resistance to multidrug isolated on the Dumai coast of Indonesia. Biodiversitas 23: 10-16. Anthropogenic pollution around the Dumai coast of Indonesia disturbs marine microorganisms, including commensal bacteria such as fecal Escherichia coli. Escherichia coli have often been used as a sensitive indicator for the spread of Antibiotic Resistance Genes (ARGs) among pathogens. This study aimed to analyze the development of E. coli resistance, originating from the Dumai sea waters using six antibiotics against seven E. coli isolates (E1, E4, E6, E8, E11, E13, and E15) at the five stations. Furthermore, a sensitivity test was performed on Mueller Hinton Agar (MHA) solid media, based on the Kirby-Bauer disk diffusion method. The results showed 100\% E. coli isolates resistant to narrow-spectrum antibiotics (Penicillin, Isoniazid, Streptomycin, and Erythromycin) at the five stations. Meanwhile, high resistance of $E$. coli against the broad-spectrum antibiotics was observed in station 4 (mangrove habitat) existed in Chloramphenicol, whilst no resistance was found in Ciprofloxacin. Escherichia coli isolates showed Multidrug Resistant (MDR) index value higher than 0.2 which suggests there is a highrisk of antibiotics pollution in Dumai seawater. Bioinformatics analysis of $16 \mathrm{~S}$ rRNA gene sequences represents the identity of $E$. coli isolates at the species level $(97.84 \%-99.74 \%)$. This study revealed the presence of antibiotic pollution in Dumai seawater which may impact public health. Hence, the local community must be disciplined about the use of antibiotics freely.
\end{abstract}

Keywords: Antibiotic pollution, biodiversity, coastal water, Escherichia coli, multidrug resistant

\section{INTRODUCTION}

Sea is one of the most important ecosystems in human life, as numerous activities and inherent natural resources tend to support the welfare of communities and countries. Based on Geographic Information Systems (GIS), Indonesia features a maritime environment with a broad proportion of water $(76.94 \%)$ compared to the total area of the Republic (Ramdhan and Arifin 2013). Furthermore, Dumai has been identified as a rapidly developing coastal area of the Riau Province with strategic water, and the city is characterized by dense industrial activities and human settlements, which contributes to the anthropogenic pollution of coastal areas (Zhao et al. 2014; Devarajan et al. 2016). This is evidenced by the presence of various industries, including oil and gas factories, palm oil mills, Fish Landing Centers (PPI), national and international ship ports (Yoswaty et al. 2021).

Anthropogenic pollution by communities residing in and around the coastal area disturbs marine microorganisms, including the high prevalence of antibiotic resistance (Nogales et al. 2011). Ecosystem disturbances in coastal waters may dispose of chain effects on health of living beings (Islam and Tanaka 2004; Phares et al. 2020). Like peoples of other countries, antibiotics are the drugs commonly used by peoples Indonesia. The pattern of antibiotic consumption was increased around $65 \%$ based on research data from 2000 to 2015 in 76 countries (Klein et al. 2018). This increase is mainly due to the low levels of knowledge, income, and facilities of society (Vila and Pal 2010). High antibiotic consumption is related to selfmedication behavior without medical procedures. The easy access to antibiotics without a doctor's prescription (Ain and Septian 2015) also added to their increased consumption. Escherichia coli multidrug-resistance was detected in Indian children that caused by demographic factors like mother's education, type of family and the access to consume antibiotics (Singh et al. 2018).

Escherichia coli is a facultatively anaerobic, rodshaped, Gram-negative bacteria of the family Enterobacteriaceae commonly found in the intestinal tract of humans and warm-blooded animals (Marflitt and Sandle 2017). Escherichia coli is one of the commensal bacteria used as the representative of the reservoir of antibiotic resistance genes (ARGs) in a marine community. Antibiotic resistance genes (ARGs) is generally carried by plasmid R, which can be easily transferred through conjugation (Silver et al. 1977). This unit consists of two parts, including the resistant transfer factor and the determinant of resistance, where both are responsible for the intrinsic nature. Furthermore, plasmid R is known to be very stable and evenly maintained, despite the small 
amount of copy at the cell division stage of bacteria (Nordström and Austin 1989), while, the transfer process between species or genus occurs with about $100 \%$ efficiency. This molecular mechanism has generally been widely studied in E. coli, while, the presence of transposons and integrons in regions of bacterial chromosomes and extra chromosomes greatly influences the nature of multidrug resistance (MDR). Also, this characteristic of gram-negative bacteria is often caused by the mechanism of multidrug efflux pumps (Nikaido 2009).

Information related to bacterial resistance is very important for human life. This is due to the use of antibiotics as a therapy for the health of humans, livestock, and cultivated fish. The Indonesian government's attention to antibiotic resistance has been started in PMK No. 8 of 2015, concerning Antimicrobial Resistance Control Program (Permenkes 2015). Therefore, this study was designed to analyze the prevalence of antibiotic resistance of E. coli bacteria found in Dumai seawater, Riau Province, with the aim of providing an overview of the nature of multidrug resistance (MDR).

\section{MATERIALS AND METHODS}

\section{Study area}

The study was conducted in the Dumai seawater, Riau Province, Indonesia between April 2019 and May 2020.

\section{Sampling}

The process of water sampling for research materials related to water quality and microorganisms content at the sampling stations did not require any special permission because these field studies did not involve endangered or protected species. Water samples were collected (roughly 1 L) just one time by purposive sampling method at 5 different stations (three points). Each point was determined by the Geographical Positioning System (GPS) coordinate (Table 1). Station 1 was in areas surrounding Industries, station 2 was nearby Settlements, station 3 was about the Harbor, station 4 was located around the Mangrove Area, and station 5 was in an area far from anthropogenic activities. The collected water samples were transferred in sterilized bottles and processed immediately with quality assurance/quality control standards (Singh et al. 2019).

\section{Isolation and identification of Escherichia coli}

The MPN (Most Probable Number) method was conducted through three stages, encompassing the presumptive, confirmed, and completed tests. Production of gas, acid formation, and abundant growth were counted from coliform samples. Briefly, three sets of tubes, each containing three tubes of Lactose Broth (Merck, Germany), with Durham's tube were inoculated with water samples (10, 1 , and $0.1 \mathrm{~mL}$ each in three sets) and incubated at $37^{\circ} \mathrm{C}$ for $48 \mathrm{~h}$. Development of turbidity, as well as gas formation, were taken as positive results and correlated with the statistical estimate of the mean number of coliforms in the sample (Rompré et al. 2002). The E. coli confirmatory test was performed by streaking the pure cultures on Eosin Methylene Blue (EMB) agar medium (Cappuccino and Sherman 2005), and characterized biochemically (Srivastava et al. 2017).

\section{Antibiotic susceptibility test}

The Kirby-Bauer disk diffusion method was implemented in microbial sensitivity tests against antibiotics based on the current Clinical and Laboratory Standards Institute (CLSI) (Patel et al. 2011). The isolates were inoculated in Mueller Hinton Broth media and incubated for $18 \mathrm{hr}$ at $37^{\circ} \mathrm{C}$. About $100 \mu \mathrm{l}$ of bacterial suspension was spread on Mueller Hinton Agar and left dried before the antibiotic disks were put on the media surface. All the samples were treated with 6 different antibiotics following (Hecht et al. 2007): Ciprofloxacin (5 $\mu \mathrm{g})$, Chloramphenicol $(30 \mu \mathrm{g})$, Penicillin $(10 \mu \mathrm{g})$, Isoniazid $(2 \mu \mathrm{g})$, Streptomycin $(10 \mu \mathrm{g})$, and Erythromycin $(15 \mu \mathrm{g})$.

\section{Determination of MDR index}

The value of the MDR index in the isolates was determined by dividing the number of resistant antibiotics by the total antibiotics tested (Hecht et al. 2007).

\section{MDR index value $=\mathrm{a} / \mathrm{b}$}

Where the variable 'a' refers to the number of antibiotics that show resistance, ' $b$ ' refers to the total number of antibiotics tested. If the isolate MDR index value $>0.2$, it revealed a high risk of antibiotic pollution from water tested environment (Joseph et al. 2017).

Table 1. The geographic coordinates of sampling stations

\begin{tabular}{|c|c|c|c|}
\hline Sites & Point 1 & Point 2 & Point 3 \\
\hline Station 1 & $01^{\circ} 41^{\prime} 27.38^{\prime \prime} \mathrm{N} ; 101^{\circ} 26^{\prime} 29.96^{\prime \prime} \mathrm{E}$ & $01^{\circ} 41^{\prime} 34.33^{\prime \prime} \mathrm{N} ; 101^{\circ} 26^{\prime} 31.12^{\prime \prime} \mathrm{E}$ & $01^{\circ} 41^{\prime} 40.17^{\prime \prime} \mathrm{N} ; 101^{\circ} 26^{\prime} 33.599^{\prime \prime} \mathrm{E}$ \\
\hline Station 2 & $01^{\circ} 41^{\prime} 21.77^{\prime \prime} \mathrm{N} ; 101^{\circ} 25^{\prime} 55.89^{\prime \prime} \mathrm{E}$ & $01^{\circ} 41^{\prime} 26.61^{\prime \prime N} ; 101^{\circ} 25^{\prime} 57.03 ” \mathrm{E}$ & $01^{\circ} 41^{\prime} 32.44^{\prime \prime} \mathrm{N} ; 101^{\circ} 25^{\prime} 59.72^{\prime \prime} \mathrm{E}$ \\
\hline Station 3 & $01^{\circ} 41^{\prime} 52.32^{\prime} \mathrm{N} ; 101^{\circ} 25^{\prime} 3.80^{\prime \prime} \mathrm{E}$ & 01'41'54.24"N; 101'25' 16.90" E & $01^{\circ} 41^{\prime} 52.22^{\prime \prime} \mathrm{N} ; 101^{\circ} 25^{\prime} 33.11^{\prime \prime} \mathrm{E}$ \\
\hline Station 4 & $01^{\circ} 42^{\prime} 18.87^{\prime \prime} \mathrm{N} ; 101^{\circ} 24^{\prime} 13.19^{\prime \prime} \mathrm{E}$ & $01^{\circ} 42^{\prime} 20.49^{\prime \prime} \mathrm{N} ; 101^{\circ} 24^{\prime} 16.53^{\prime \prime} \mathrm{E}$ & $01^{\circ} 42^{\prime} 31.04^{\prime \prime} \mathrm{N} ; 101^{\circ} 24 ’ 20.48^{\prime \prime} \mathrm{E}$ \\
\hline Station 5 & $01^{\circ} 42^{\prime} 40.44^{\prime \prime} ; 101^{\circ} 24 ’ 21.70^{\prime \prime} \mathrm{E}$ & $01^{\circ} 42^{\prime} 46.94 ’ \mathrm{~N} ; 101^{\circ} 24 ’ 25.79^{\prime \prime} \mathrm{E}$ & $01^{\circ} 42^{\prime} 54.60^{\prime \prime N} ; 101^{\circ} 24^{\prime} 29.04^{\prime \prime} \mathrm{E}$ \\
\hline
\end{tabular}

Note: N: North; E: East 


\section{DNA extraction and characteristic of 16S rRNA bacteria}

The pure culture of E. coli was used as samples subjected to amplification process by PCR techniques (Senbadejo 2017). We used a Qiagen PCR kit and universal 16S rRNA primers like 24F (5'-AGAGTTTGATCCT GGCTCAG-'3) (Lane 1991) and 1541R (5'AAGGAGGTGATCCAGCCGCA-'3) (Massol-Deya et al. 1997). The visualization of PCR products was done on agarose gel $(1 \%)$ for the confirmation test. The PCR product was sequenced to identify homology levels of samples with GenBank data sequences (http://www.ncbi.nlm.nib.gov/) using the BLASTN software.

\section{Phylogenetic tree construction}

The $E$. coli samples were aligned with $E$. coli sequences downloaded from the GenBank data using ClustalW software. The phylogenetic tree was constructed using the UPGMA model in the MEGA X software.

\section{RESULTS AND DISCUSSION}

The central industrial area of Indonesia is well known in Dumai city, Riau Province due to high anthropogenic activities (Yoswaty et al. 2021). It is located on the east coast of the island of Sumatra and is situated in Malaysia's outer waters bordering.

The Indonesian Ministry of the Environment stated on the quality standards about the total of coliform bacteria and $E$. coliform in the marine environment must not exceed $1000 \mathrm{CFU} / 100 \mathrm{~mL}$ and $200 \mathrm{CFU} / 100 \mathrm{ml}$, respectively (Hidup 2004). The density of $E$. coli at the 5 stations in Dumai seawater has exceeded the Ministry of the Environment standards (Figure 1), with the lowest value at station $5\left(2.37 \times 10^{2} \mathrm{CFU} / 100 \mathrm{~mL}\right)$, which was identified as an area far from anthropogenic pollution. However, the density of $E$. coli at stations 2 and $3\left(1.1 \times 10^{3}\right.$ CFU/100 $\mathrm{mL}$ ), known as an area prone to anthropogenic pollution (Feliatra et al. 2020; Feliatra et al. 2021), showed a higher coliform count because of the location near the harbor and densely settlements. Conversely, station $4\left(7.45 \times 10^{2}\right.$ CFU/100 mL) features a mangrove habitat, while station 1 (4.23 $\mathrm{x} 10^{2} \mathrm{CFU} / 100 \mathrm{~mL}$ ) is an industrial area (Lukistyowati et al. 2019). Indonesia's Ministry of Environment is in line with the international regulations issued by WHO, which stipulated a maximum limit of $E$. coliform ( $\leq 200 \mathrm{CFU} / 100 \mathrm{~mL}$ ) for activities in the field of aquaculture (Santé et al. 2004). A similar study was revealed in river Krishna, India, where is the total coliform and fecal coliform counts were found in a range of $16 \times 10^{2}$ to $24 \times 10^{6} \mathrm{CFU} / 100 \mathrm{~mL}$ (Dhakyanaika and Kumara 2010).

MPN testing has been widely used for monitoring the water quality from coliform bacteria contamination. The $\mathrm{pH}$ range of Dumai seawater at the 5 stations $(6.7-7.3)$ strongly supports the growth of E. coli bacteria (Tururaja and Mogea 2010), with the presence of dissolved oxygen at about 8.0-8.6 ppm, which was categorized in good condition. Furthermore, the tidal currents range from 0.06-
$0.2 \mathrm{~m} / \mathrm{s}$, and temperatures of $30.1-30.7^{\circ} \mathrm{C}$ were identified as supporting factors for the high density of $E$. coli which is currently at an unhealthy level. This is the cause of low awareness on the part of the community and government towards the management and sanitation of waste streams, which subsequently threatens public health. Escherichia coli which pollutes the waters can cause diarrhea, in the form of endotoxins produced by virulence factors (Prejit and Latha 2007).

Based on the identification of morphological, biochemical, and molecular processes, there were only 7 out of 17 isolates confirmed as E. coli. Other isolates only show homology under $95 \%$ after the sequencing analysis (genus level). E1 and E4 were isolated from station 1, E6 and E8 were represented from stations 2 and 3 respectively, E11 and E13 were collected from station 4, and last station 5 was represented by E15. All isolates were tested to antibiotic sensitivity based on the provisions of the current Clinical and Laboratory Standards Institute (CLSI), and the three criteria include resistance (R) with a $0-10 \mathrm{~mm}$ resistance zone, intermediates (I) at 11-19 $\mathrm{mm}$, and sensitive (S) at above $20 \mathrm{~mm}$ (Wayne 2010). Furthermore, this study uses two groups of antibiotics, including broadspectrum (Ciprofloxacin and Chloramphenicol) and narrow-spectrum (Penicillin, Isoniazid, Streptomycin, and Erythromycin) in Table 2. The selection of antibiotics was based on the common types that farmers used in pond feeds (Jayaprakash and Bright 2005). The results obtained from antibiotic power on E. coli isolates are shown in Figure 2.

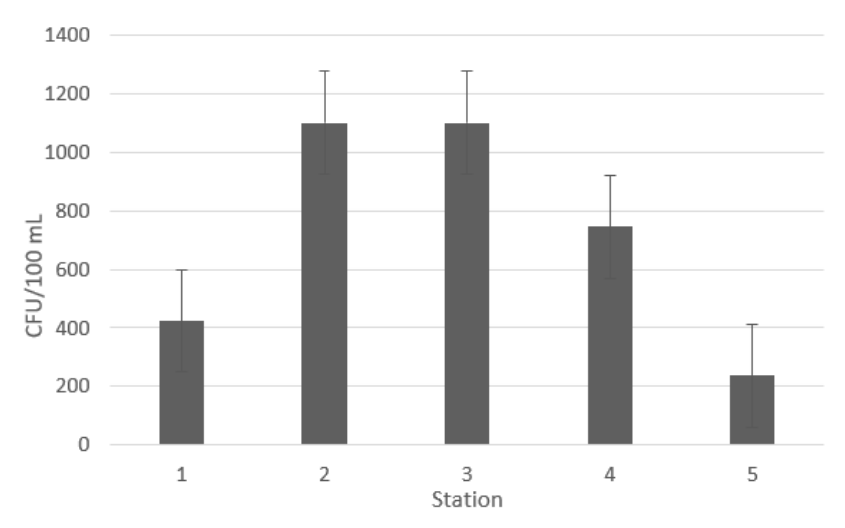

Figure 1. Escherichia coli density from 5 stations in Dumai seawater, Riau Province, Indonesia

Table 2. Percentage of Escherichia coli isolates resistance against antibiotics

\begin{tabular}{llcccccc}
\multicolumn{1}{c}{ Antibiotics } & \multirow{2}{*}{ S } & \multirow{2}{*}{ I } & \multirow{2}{*}{ R } & \multicolumn{3}{c}{ Percentage (\%) } \\
\cline { 6 - 8 } & & & & S & I & R \\
\hline Broad- & Ciprofloxacin & 1 & 6 & 0 & 14 & 86 & 0 \\
spectrum & Chloramphenicol & 0 & 5 & 2 & 0 & 71 & 29 \\
Narrow- & Penicillin & 0 & 0 & 7 & 0 & 0 & 100 \\
spectrum & Isoniazid & 0 & 0 & 7 & 0 & 0 & 100 \\
& Streptomycin & 0 & 0 & 7 & 0 & 0 & 100 \\
& Erythromycin & 0 & 0 & 7 & 0 & 0 & 100 \\
\hline
\end{tabular}




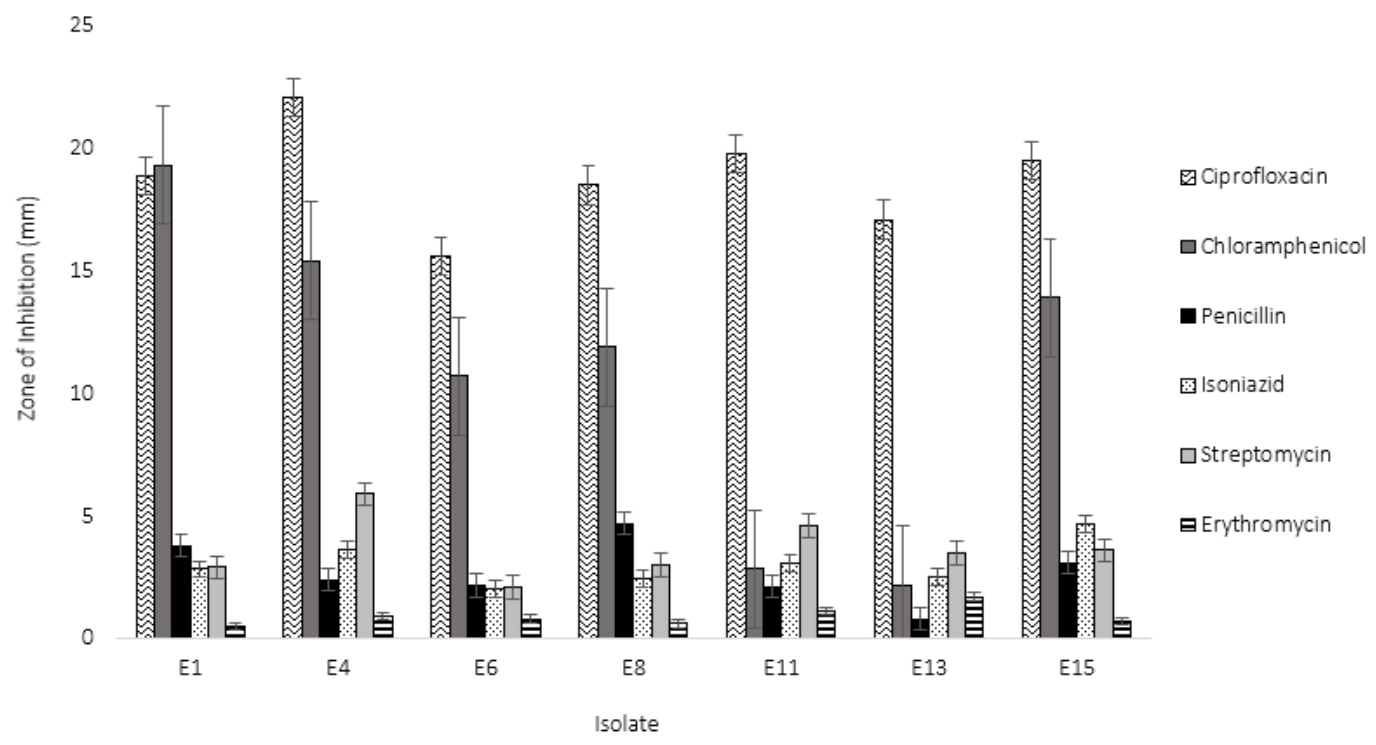

Figure 2. Results of the average resistance test of Escherichia coli isolates against antibiotics

The result from Table 2 and Figure 2 show that most $E$. coli tested have high resistance against all the narrowspectrum antibiotics (Penicillin, Isoniazid, Streptomycin, and Erythromycin). The E. coli resistance to Chloramphenicol was found on isolates E11 and E13, whilst, no resistance of $E$. coli to Ciprofloxacin was found. The condition was also reported in Malaysia coastal waters that showed a high percentage of bacteria resistance to narrow-spectrum than broad-spectrum such as Chloramphenicol (Kian et al. 2012). The sensitivity test of Ciprofloxacin is quite good, because of its penetration properties in bacteria cells or tissues, and its inherent action of inhibiting Topoisomerase II and IV (Chohan et al 2005). Antibiotics pollution not only occurred in developing countries but also happened in the universal, it is a global problem regards anthropogenic effects ( $\mathrm{Na}$ et al. 2018).

Both isolates (E11 and E13) were isolated from the mangrove habitat (station 4), which is location near with aquaculture pond. The fact of biogeochemical cycles in mangrove ecosystems was contributed by anthropogenic waste and there has been a correlation to ARG potency in microbiota (Jiang et al. 2021). For example, by using Chloramphenicol in fish feed as an effort of farmers to treat fish infections. Consequently, it may affect heterotrophic bacteria from the water where it becomes resistant to Chloramphenicol as same as narrow-spectrum (Manivasagan et al. 2011; Javid et al. 2020). This reflected high antibiotic pollution in the water. It also conferred that indigenous bacteria could be considered as bio-indictors of antibiotic pollution (Al-Bahry et al. 2009).

The multidrug resistance (MDR) index value of each sample was calculated to determine the $E$. coli resistance to multidrug (Ab Rahman et al. 2015; Mardalisa et al. 2021). The Multidrug Resistance (MDR) index based on the data in Table 2 was calculated to be 0.714 (> 0.2). Even though, this study has small data, its patterns were succeeded to support the recent study about antibiotic pollution in Indonesia (Reverter et al. 2020). It is assumed that usage of antibiotics more freely may lead to the development of $E$. coli resistance, so its bad effect contributed to infection problems in humans and animals (Krisnaningsih et al. 2005). This is supported by drug providers who sell antibiotics without a doctor's prescription (Ain and Septian 2015). The Indonesian government already set the rules on PMK RI No. 8 of 2015 to avoid the use of inappropriate and high antibiotic doses, due to the inherent potential of MDR (Permenkes 2015).

Most of the Gram-negative bacteria including E. coli are pathogenic to humans. A previous study reported that antibiotic resistance genes (ARGs) in plasmid $R$ were transferred between the pathogenic and nonpathogenic Gram-negative bacteria in the aquatic environment with high antibiotic pollution (Zhang et al. 2011). Escherichia coli could be a host for the transmission of antibiotic resistance genes (ARGs) in the food chain via fish and other infected marine biotas. The possibility of crossresistance to produce proteins encoded by the affiliated resistance genes (ARGs) in plasmid $\mathrm{R}$ (Al-Bahry et al. 2006).

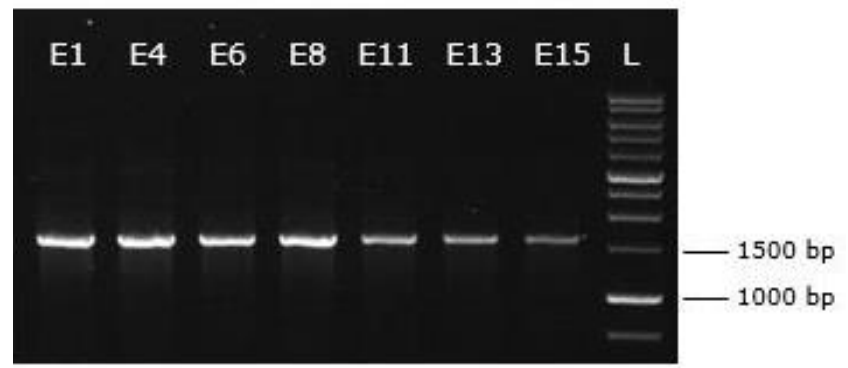

Figure 3. Gel electrophoresis of 16S rRNA from Escherichia coli isolates. L: $1 \mathrm{~kb}$ DNA ladder 
Table 3. BLASTN analysis result from Escherichia coli isolates

\begin{tabular}{lllcccc}
\hline Isolate & Species & Strain & Access code & Query coverage & Homology & Station \\
\hline E1 & E. coli & NBRC 102203 & NR 114042.1 & $98 \%$ & $98.68 \%$ & 1 \\
E4 & E. coli & JCM 1649 & NR 112558.1 & $76 \%$ & $99.74 \%$ & 1 \\
E6 & E. coli & JCM 1649 & NR 112558.1 & $76 \%$ & $98.74 \%$ & 2 \\
E8 & E. coli & NBRC 102203 & NR 114042.1 & $98 \%$ & $98.12 \%$ & 3 \\
E11 & E. coli & U 5/41 & NR 024570.1 & $99 \%$ & $98.62 \%$ & 4 \\
E13 & E. coli & NBRC 102203 & NR 114042.1 & $98 \%$ & $97.84 \%$ & 4 \\
E15 & E. coli & U 5/41 & NR 114042.1 & $99 \%$ & $98.41 \%$ & 5 \\
\hline
\end{tabular}
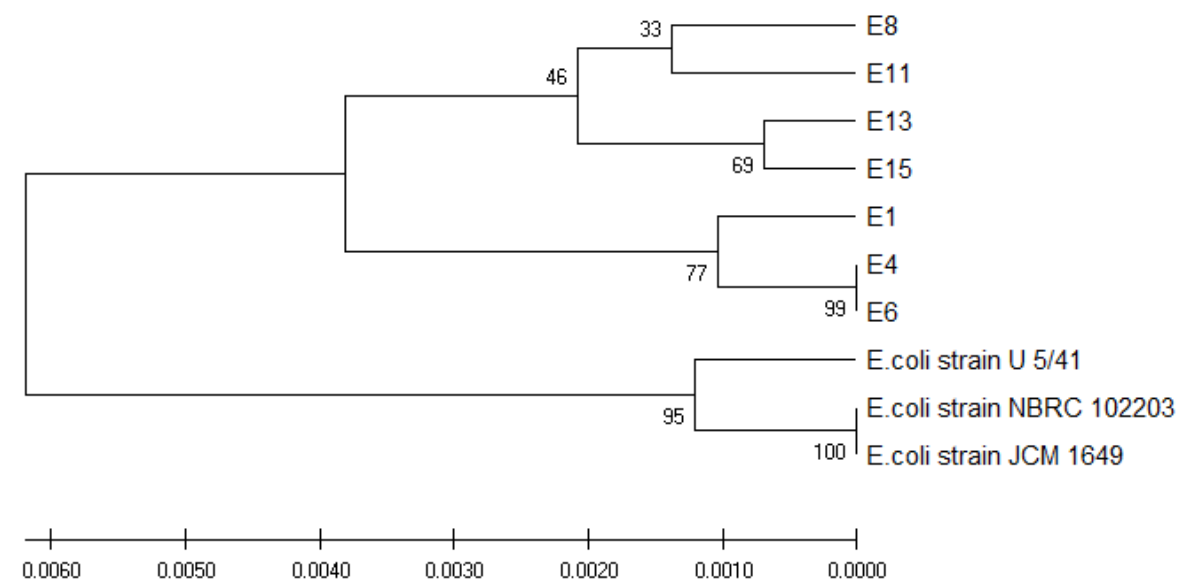

Figure 4. Phylogenetic tree for Escherichia coli isolates using UPGMA method

Identification of $E$. coli isolates was done by molecular test that used DNA barcode 16S rRNA. All isolates were successfully amplified by PCR technique using 24F and 1541R primers (Mardalisa et al. 2021). The results showed a single band for all samples at a size of around $1500 \mathrm{bp}$ in $1 \%$ agarose gel (Figure 3). The $16 \mathrm{~S}$ rRNA gene is the highly conserved region to identify the diversities in prokaryotic organisms and evolutionary relationships between prokaryotic strains (Mardalisa et al. 2020).

$16 \mathrm{~S}$ rRNA gene analysis is based on the detection of sequence differences (polymorphisms) in the hypervariable regions of the 16S rRNA gene which $97 \%$ of sequence similarity is recognized in the same species. Bioinformatic analysis showed that all samples show the homology level range from $97.84 \%$ to $99.74 \%$ to $E$. coli data in GenBank (Table 3) (Kim et al. 2014). Homology percentage in BLASTN analysis result showed the statistically significant similarity that reflects common ancestry based on sequence DNA (Pearson 2013).

The identification of the kinship for $E$. coli isolates was conducted using the UPGMA method, characterized by Multiple Alignments (MA) that aligns sequences of similar length (Figure 4). Based on the principle of Wunsch Needleman Algorithm, the branch length from the parent to the two-child nodes was the same (Malendes and Bunyamin 2017).

The study revealed that $E$. coli isolates obtained from Dumai seawater showed multidrug resistance. Therefore, it is necessary for all the local communities to be disciplined in using antibiotics.

\section{ACKNOWLEDGEMENTS}

The authors wish to sincere gratitude to Civitas Academica from Department of Marine Science, Universitas Riau, Indonesia for their cooperation and active support in this study. The authors say thank to the LPPM of Universitas Riau and Ministry of Education, Culture, Research, and Technology (Kemdikbudristek), Indonesia for their continuous support and help throughout the study.

\section{REFERENCES}

Ab Rahman N, Chowdhury AJ, Abidin ZA. 2015. Antibiotic resistant bacteria from sediment of coastal water of Pahang, Malaysia. Jurnal Teknologi 77 (24): 65-70. DOI: 10.11113/jt.v77.6709.

Ain H, Septian F. 2015. Perilaku masyarakat tentang penggunaan antibiotika oral. Medica Majapahit 7 (1): 79-90. [Indonesian]

Al-Bahry S, Mahmoud I, Al-Belushi K, Elshafie A, Al-Harthy A, Bakheit C. 2009. Coastal sewage discharge and its impact on fish with reference to antibiotic resistant enteric bacteria and enteric pathogens as bio-indicators of pollution. Chemosphere 77: 1534-1539. DOI: 10.1016/j.chemosphere.2009.09.052.

Al-Bahry SN, Al-Mashani BM, Elshafie AE, Pathare N, Al-Harthy AH. 2006. Plasmid profile of antibiotic resistant Escherichia coli isolated from chicken intestines. J Alabama Acad Sci 77 (11): 152-159. 
Cappuccino JG, Sherman N. 2005. San Francisco: Pearson/Benjamin Cummings. In: Sultenfuss JH, Doyle WJ. 1999. Functions of phosphorus in plants. Better Crops 83 (1): 6-7.

Chohan ZH, Supuran CT, Scozzafava A. 2005. Metal binding and antibacterial activity of ciprofloxacin complexes. J Enzyme Inhib Med Chem 20 (3): 303-307. DOI: 10.1080/14756360310001624948.

Devarajan N, Laffite A, Mulaji CK, Otamonga J-P, Mpiana PT, Mubedi JI, Prabakar K, Ibelings BW, Poté J. 2016. Occurrence of antibiotic resistance genes and bacterial markers in a tropical river receiving hospital and urban wastewaters. PloS One 11 (2): e0149211. DOI: 10.1371/journal.pone.0149211.

Dhakyanaika K, Kumara P. 2010. Effects of pollution in River Krishni on hand pump water quality. J Eng Sci Technol Rev 3 (1): 14-22. DOI: DOI: $10.25103 /$ jestr.031.03.

Feliatra F, Mardalisa M, Setiadi J, Lukistyowaty I, Hutasoit AY. 2020 Potential of secondary metabolite from marine heterotrophic bacteria against pathogenic bacteria in aquaculture. J Phys: Conf Ser 1655 (1): 012044.

Feliatra F, Mardalisa M, Mukti PR, Feliatra VA, Effendi I. 2021. Potential of Bacillus cereus SN7 as a single cell protein source. J Phys: Conf Ser 2049 (1): 012024.

Hecht DW, Citron DM, Cox M, Jacobus N, Jenkins S, Onderdonk A, RoeCarpenter D, Rosenblatt J, Wexler H. 2007. Methods for antimicrobial susceptibility testing of anaerobic bacteria: approved standard. National Committee for Clinical Laboratory Standards.

Hidup KL. 2004. Pedoman penetapan baku mutu lingkungan. In: Jakarta: Kantor Menteri Negara Kependudukan Lingkungan Hidup. Keputusan Menteri Negara Kependudukan dan Lingkungan Hidup. Kep-51/MNLH. [Indonesian]

Islam MS, Tanaka M. 2004. Impacts of pollution on coastal and marine ecosystems including coastal and marine fisheries and approach for management: a review and synthesis. Mar Pollut Bull 48 (7-8): 624 649. DOI: 10.1016/j.marpolbul.2003.12.004.

Javid P, Shahabadi HZ, Amirkhani H, Amrollahi N, Ranjbar MS. 2020 Isolation and identification of halophilic and halotolerant bacteria from the sediments of the Qeshm Island mangrove forest. Adv Oceanogr Limnol 11 (1): 1-10. DOI: 10.4081/aiol.2020.8743.

Jayaprakash NS, Bright Singh IS. 2005. Antibody-based diagnostic for detection of Vibrios and their biological control using antagonistic bacteria in Macrobrachium rosenbergii larval rearing systems. [Dissertation]. School of Environmental Studies. Co Chin University of Science and Technology, Cochin, Kerala.

Jiang C, Diao X, Wang H, Ma S. 2021. Diverse and abundant antibiotic resistance genes in mangrove area and their relationship with bacterial communities-A study in Hainan Island, China. Environ Pollut 276 (1): 116704. DOI: 10.1016/j.envpol.2021.116704.

Joseph A, Odimayo M, Olokoba L, Olokoba A, Popoola G. 2017. Multiple antibiotic resistance index of Escherichia coli isolates in a tertiary hospital in southwest Nigeria. Med J Zambia 44 (4): 225-232.

Kian GY, Chui WB, Choon WL. 2012. Antimicrobial resistance in bacteria isolated from tropical coastal waters of Peninsular Malaysia. Malays J Sci 31 (2): 111-120. DOI: 10.22452/mjs.vol31no2.9.

Kim M, Oh H-S, Park S-C, Chun J. 2014. Towards a taxonomic coherence between average nucleotide identity and $16 \mathrm{~S}$ rRNA gene sequence similarity for species demarcation of prokaryotes. Intl J Syst Evol Microbiol 64 (2): 346-351. DOI: 10.1099/ijs.0.059774-0.

Klein EY, Van Boeckel TP, Martinez EM, Pant S, Gandra S, Levin SA, Goossens H, Laxminarayan R. 2018. Global increase and geographic convergence in antibiotic consumption between 2000 and 2015. Proc Nat Acad Sci 115 (15): E3463-E3470. DOI 10.1073/pnas.1717295115.

Krisnaningsih MF, Asmara W, Wibowo MH. 2005. Uji sensitivitas isolat Escherichia coli patogen pada ayam terhadap beberapa jenis antibiotik. J Sain Veteriner 23 (1): 13-18. DOI: 10.22146/jsv.361. [Indonesian]

Lane D. 1991. 16S/23S rRNA sequencing. In: Stackebrandt E, Goodfellow M [eds] Nucleic acid techniques in bacterial systematics. John Wiley \& Sons, Chichester, UK.

Lukistyowati I, Feliatra F, Nursyiwarni N, Qoriman A, Leksnono T, Mulyadi A. 2019. Microbiological quality (pathogen E. coli bacteria) in the coastal environment of Dumai City, Riau Province. IOP Conf Ser: Earth Environ Sci 348 (1): 012009. DOI: 10.1088/17551315/348/1/012009.

Malendes MA, Bunyamin H. 2017. Analisa perbandingan dan implementasi algoritma DNA pairwise sequence alignmen Needleman-Wunsch dan Lempel-Ziv. J Teknik Informatika dan
Sistem Informasi 3 (1): 57-68. DOI: 10.28932/jutisi.v3i1.568. [Indonesian]

Manivasagan P, Rajaram G, Ramesh S, Ashokkumar S, Damotharan P. 2011. Occurrence and seasonal distribution of antibiotic resistance heterotrophic bacteria and physicochemical characteristics of Muthupettai mangrove environment, southeast coast of India. J Environ Sci Technol 4 (1): 139-149. DOI: 10.3923/jest.2011.139.149.

Mardalisa M, Suhandono S, Ramdhani M. 2020. Isolation and characterization of str promoter from bacteria Escherichia coli DH5 $\alpha$ using reporter gene AmilCP (Acropora millepora). IOP Conf Ser: Earth Environ Sci 430 (1): 012014.

Mardalisa M, Feliatra F, Nursyirwani N. 2021. Multiple antibiotic resistance index of Escherichia coli isolates from Dumai sea waters Riau Province. Berkala Perikanan Terubuk 49 (1): 734-739. DOI: 10.31258/terubuk.49.1.734-739.

Mardalisa M, Suhandono S, Yanti N, Rozi F, Nova F. 2021. Bioinformatic analysis in designing mega-primer in overlap extension PCR cloning (OEPC) technique. Intl J Inf Visualization 5 (2): 139-143. DOI: 10.30630/joiv.5.2.459

Marflitt A, Sandle T. 2017. Evaluation of Readycult® coliforms 100 presence/absence test for the screening of coliforms and Escherichia coli in pharmaceutical water samples. Eur J Parenter Pharm Sci 22 (4): 118-125

Massol-Deya A, Weller R, Rios-Hernandez L, Zhou J, Hickey R, Tiedje J. 1997. Succession and convergence of biofilm communities in fixedfilm reactors treating aromatic hydrocarbons in groundwater. Appl Environ Microbiol 63 (1): 270-276. DOI: 10.1128/aem.63.1.270276.1997.

Na G, Lu Z, Gao H, Zhang L, Li Q, Li R, Yang F, Huo C, Yao Z. 2018. The effect of environmental factors and migration dynamics on the prevalence of antibiotic-resistant Escherichia coli in estuary environments. Sci Rep 8 (1): 1-9. DOI: 10.1038/s41598-018-20077-x.

Nikaido H. 2009. Multidrug resistance in bacteria. Ann Rev Biochem 78: 119-146. DOI: 10.1146/annurev.biochem.78.082907.145923.

Nogales B, Lanfranconi MP, Piña-Villalonga JM, Bosch R. 2011. Anthropogenic perturbations in marine microbial communities. FEMS Microbiol Rev 35 (2): 275-298. DOI: 10.1111/j.15746976.2010.00248.x

Nordström K, Austin SJ. 1989. Mechanisms that contribute to the stable segregation of plasmids. Ann Rev Genet 23 (1): 37-69. DOI: 10.1146/annurev.ge.23.120189.000345.

Patel JB, Tenover FC, Turnidge JD, Jorgensen JH. 2011. Susceptibility test methods: dilution and disk diffusion methods. In: Manual of Clinical Microbiology, 10th Edition. Amer Soc Microbiol 1122-1143. DOI: 10.1128/9781555817381.ch71.

Pearson WR. 2013. An introduction to sequence similarity ("homology") searching. Curr Protoc Bioinformatics 42 (1): 311-318. DOI: 10.1002/0471250953.bi0301s42.

Permenkes R. 2015. Program pengendalian resistensi antimikroba di rumah sakit. Menteri Kesehatan Republik Indonesia, Jakarta. [Indonesian]

Phares CA, Danquah A, Atiah K, Agyei FK, Michael O-T. 2020. Antibiotics utilization and farmers' knowledge of its effects on soil ecosystem in the coastal drylands of Ghana. PloS One 15: e0228777. DOI: 10.1371/journal.pone.0228777.

Prejit NE, Latha C. 2007. Microbial quality assurance of milk during production, processing, and marketing. Amer J Food Technol 2 (3): 136-144. DOI: 10.3923/ajft.2007.136.144

Ramdhan M, Arifin T. 2013. Aplikasi sistem informasi geografis dalam penilaian proporsi luas laut Indonesia. Jurnal Ilmiah Geomatika 19 (2): 141-146. [Indonesian]

Reverter M, Sarter S, Caruso D, Avarre JC, Combe M, Pepey E, Pouyaud L, VegaHeredía S, De Verdal H and Gozlan RE. 2020. Aquaculture at the crossroads of global warming and antimicrobial resistance. Nat Commun 11 (1): 1-8. DOI: 10.1038/s41467-020-15735-6.

Rompré A, Servais P, Baudart J, De-Roubin M-R, Laurent P. 2002. Detection and enumeration of coliforms in drinking water: current methods and emerging approaches. J Microbiol Methods 49 (1): 31 54. DOI: 10.1016/s0167-7012(01)00351-7.

santé Omdl, Organization WH, programme W--W, Staff WHO, Zdrowia Ś, WHO. 2004. Guidelines for drinking-water quality: World Health Organization.

Senbadejo TY. 2017. Antibiotic susceptibility patterns of Pseudomonas species isolated from clinical and environmental samples in Awba Dam, Ibadan. Fountain J Nat Appl Sci 6 (2): 9-14. DOI: 10.53704/fujnas.v6i2.149. 
Silver L, Chandler M, de la Tour EB, Caro L. 1977. Origin and direction of replication of the drug resistance plasmid R100. 1 and of a resistance transfer factor derivative in synchronized cultures. J Bacteriol 131 (3): 929-942. DOI: 10.1128/jb.131.3.929-942.1977.

Singh AK, Das S, Singh S, Gajamer VR, Pradhan N, Lepcha YD, Tiwari HK. 2018. Prevalence of antibiotic resistance in commensal Escherichia coli among the children in rural hill communities of Northeast India. PloS One 13 (6): 0199179. DOI 10.1371/journal.pone.0199179.

Singh AK, Das S, Singh S, Pradhan N, Gajamer VR, Kumar S, Lepcha YD, Tiwari HK. 2019. Physicochemical parameters and alarming Coliform count of the potable water of Eastern Himalayan state Sikkim: An indication of severe fecal contamination and immediate health risk. Front Publ Health 7 (174): 1-17. DOI 10.3389/fpubh.2019.00174.

Srivastava S, Dash HR, Das S. 2017. Assessment of the biological quality of riverine water using pathogenicity islands (PAIs) of coliform bacteria as pollution indicator. Water Resour 44 (1): 150-157. DOI: 10.1134/S0097807817010146

Tururaja T, Mogea R. 2010. Bakteri coliform di perairan Teluk Doreri, Manokwari aspek pencemaran laut dan identikasi species. Ilmu Kelautan: Indones J Mar Sci 15 (1): 47-52. [Indonesian]
Vila J, Pal T. 2010. Update on antibacterial resistance in low-income countries: factors favoring the emergence of resistance. Open Infect Dis J 4 (1): 38-54. DOI: 10.2174/1874279301004010038.

Wayne P. 2010. Clinical and laboratory standards institute: Performance standards for antimicrobial susceptibility testing: 20th informational supplement. CLSI document M100-S20.

Yoswaty D, Amin B, Fatwa EB, Pakpahan D. 2021. Identification of microplastic waste in seawater, sediment in the sea waters of Dumai City, Riau Province. IOP Conf Ser: Earth Environ Sci 674 (1): 012113. DOI: 10.31258/ajoas.3.3.248-259.

Yoswaty D, Effendi I, Mardalisa M, Efriyeldi E, Makwa AMM, Dzikri MF. 2021. The threat of microplastic waste in Dumai waters, Province of Riau, Indonesia. Carpathian J Earth Environ 16 (2): 383390. DOI: $10.26471 /$ cjees/2021/016/183

Zhang YB, Li Y, Sun XL. 2011. Antibiotic resistance of bacteria isolated from shrimp hatcheries and cultural ponds on Donghai Island, China. Mar Pollut Bull 62 (11): 2299-2307. DOI: 10.1016/j.marpolbul.2011.08.048.

Zhao H, Li Q, Tao J. 2014. Spatio-temporal patterns and source identification of surface water pollution in Bohai Bay, China from 1995 to 2005. World J Eng 11 (6): 605-612. DOI: 10.1260/17085284.11.6.605. 